\title{
FAKTOR-FAKTOR YANG MEMPENGARUHI KEPUTUSAN NASABAH MENGGUNAKAN LAYANAN INTERNET BANKING PT. BANK MESTIKA RANTAUPRAPAT
}

\author{
Herwin Chandra ${ }^{1}$, Elida Florentina Sinaga Simanjorang ${ }^{2}$ \\ ${ }^{1}$ Alumni STIE Labuhanbatu \\ ${ }^{2}$ Dosen STIE Labuhanbatu
}

\begin{abstract}
ABSTRAK
Hasil penelitian ini menunjukkan bahwa secara parsial faktor persepsi kemudahan penggunaan (perceived easy of use) $\left(\mathrm{X}_{1}\right)$, persepsi manfaat (perceived usefulness) $\left(\mathrm{X}_{2}\right)$, dan kepercayaan (trust) $\left(\mathrm{X}_{3}\right)$ berpengaruh positif dan signifikan terhadap keputusan nasabah untuk menggunakan Internet Banking PT. Bank Mestika Rantauprapat, sedangkan faktor resiko (risk) $\left(\mathrm{X}_{4}\right)$ berpengaruh positif dan tidak signifikan terhadap keputusan nasabah untuk menggunakan Internet Banking PT. Bank Mestika Rantauprapat. Secara simultan (serempak) faktor persepsi kemudahan penggunaan (perceived easy of use) ( $\left.\mathrm{X}_{1}\right)$, persepsi manfaat (perceived usefulness) $\left(\mathrm{X}_{2}\right)$, dan kepercayaan (trust) $\left(\mathrm{X}_{3}\right)$, dan resiko (risk) $\left(\mathrm{X}_{4}\right)$ berpengaruh positif dan signifikan terhadap keputusan nasabah menggunakan layanan internet banking pada PT. Bank Mestika Rantauprapat. Berdasarkan pengujian koefisien Determinan $\left(R^{2}\right)$, dapat diketahui nilai koefisien determinan $\left(R^{2}\right)$ sebesar 0,352 yang artinya $35,2 \%$ dari keputusan nasabah untuk menggunakan Internet Banking dapat dijelaskan oleh faktor persepsi kemudahan penggunaan (perceived of easy of use), persepsi manfaat (perceived of usefullness), kepercayaan (trust), dan resiko (risk), sedangkan sisanya sisanya sebesar 64,8\% dijelaskan faktor lain yang tidak diteliti.
\end{abstract}

Kata Kunci: Persepsi Kemudahan Penggunaan, Persepsi Manfaat, Kepercayaan, Keputusan Nasabah.

\section{Pendahuluan}

Layanan internet banking diberikan oleh bank dengan tujuan utama memberikan kemudahan kepada para nasabah. Pelayanan perbankan melalui internet tersebut berupa situs dari suatu bank tertentu yang menyediakan pelayanan perbankan langsung tanpa perlu datang ke bank yang bersangkutan. Dengan adanya situs itu, nasabah suatu bank akan semakin mudah untuk melakukan kegiatan perbankan, karena para nasabah dapat mengakses layanan yang diinginkan oleh nasabah saja, tanpa harus datang ke bank yang bersangkutan.
Perkembangan teknologi internet ini diadopsi oleh industri perbankan untuk mengembangkan pelayanan. Peluang ini digunakan oleh bank-bank yang ada di Indonesia, baik bank pemerintah maupun swasta. Karena media internet adalah suatu inovasi yang cukup memberikan peluang dan menantang dalam pengembangannya. Perkembangan pelayanan yang dilakukan perbankan berbasis teknologi (electronic transaction) dalam bentuk internet banking, mobile banking, phone banking, ATM (Authomatic Teller Machine), Credit Card dan lain sebagainya. Saat ini internet banking menjadi perhatian utama 
dan senjata yang revolusioner strategis operasional bank, untuk menyampaikan maupun untuk persaingan antar bank.

Nasabah bank di Indonesia masih banyak yang menggunakan internet banking hanya sekedar melihat saldo, oleh sebab itu bank perlu meningkatkan strategi agar semakin banyak nasabah yang menggunakan internet dengan tujuan agar value yang diberikan nasabah bank semakin tinggi. Transaksi e-payment dapat lebih dikembangkan dalam aktivitas bisnis sehingga nasabah bank benar-benar merasakan manfaat internet banking ini. Untuk mempermudah dan mempercepat proses pembayaran sangat dibutuhkan bantuan teknologi. Teknologi masa kini identik dengan komputerisasi. Tentu kemudahan bertransaksi melalui internet banking merupakan salah satu cara dan upaya para bankir untuk mempengaruhi nasabah dalam menggunakan layanan bank tersebut. Salah satu bank yang menawarkan jasa internet banking adalah PT. Bank Mestika.

Perkembangan teknologi ini pun diantisipasi oleh perusahaan-perusahaan, baik penyedia barang ataupun jasa. Terobosan-terobosan baru harus dirancang agar dapat terus berkembang dan bersaing, atau paling tidak mempertahankan eksistensi. PT. Bank Mestika sebagai salah satu institusi perbankan sangat menyadari bahwa pelayanan kepada nasabah harus pula dengan menyesuaikan pada kemajuan teknologi, artinya dengan bersentuhan pada teknologi maka Bank Mestika akan tetap dapat bersaing. Oleh karena itu, Bank Mestika meluncurkan layanan mobile banking.

Saat ini jenis pelayanan pada Bank Mestika internet banking diklasifikasikan sesuai dengan kebutuhan nasabah yaitu : Internet Banking Info dimana nasabah dapat memperoleh berbagai macam informasi seperti saldo rekening, mutasi rekening dan lain-lain. Mobile banking transfer adalah layanan yang memudahkan untuk nasabah melakukan transfer antar rekening Bank Mestika maupun ke bank lainnya. Mestika Banking Payment dimana nasabah dapat melakukan transaksi pembayaran berbagai macam tagihan seperti tagihan televisi kabel, telepon, asuransi dan lain-lain. Mestika Banking Commerce dimana nasabah dapat melakukan berbagai macam transaksi pembelian dan pembayaran seperti pulsa isi ulang, saham dan lain-lain. Mestika Banking Admin dimana nasabah dapat melakukan berbagai transaksi administrasi seperti ganti PIN dan lainlain.

Peluncuran layanan Mestika internet banking membuat nasabah Bank Mestika yang menggunakan layanan tersebut merasa memiliki ATM dalam gengaman tangan dimana berbagai transaksi perbankan dapat dilakukan melalui ponsel, semudah bertransaksi di ATM Bank Mestika. PT Bank Bank Mestika tentu saja terus berusaha mengembangkan pelayanannya dengan sebaik mungkin agar para nasabah puas dan sesuai dengan konsep pemasaran, nasabah tersebut akan terus mempercayai Bank Mestika untuk transaksi keuangannya. Dari jumlah nasabah Bank Mestika cabang Rantauprapat, persentase pengguna layanan internet banking masih sangat minim. Dari sekitar 159.690 orang nasabah, pengguna layanan internet banking pada Bank Mestika cabang Rantauprapat hanya 2.450 orang nasabah (sumber : customer service Bank Mestika Cabang Rantauprapat).

Upaya untuk mempromosikan layanan Mestika internet banking sudah 
dilakukan pihak Bank Mestika dengan media iklan dan penayangan program khusus. Hal ini tentunya mengundang pertanyaan, faktor yang menyebabkan masih rendahnya jumlah pemakai Mestika Internet Banking. Karena upaya promosi telah dilakukan, maka faktor lain yang menjadi pertanyaan adalah tentang keputusan nasabah pengguna internet banking.

\section{Tinjauan Pustaka}

\section{Pengertian Pemasaran Bank}

Dunia perbankan merupakan badan usaha yang berorientasi profit, kegiatan pemasaran sudah merupakan suatu kebutuhan utama dan sudah merupakan suatu keharusan untuk dijalankan. Tanpa kegiatan pemasaran jangan diharapkan kebutuhan dan keinginan nasabahnya akan terpenuhi.

Menurut Kasmir (2008:63)

pemasaran bank adalah suatu proses untuk menciptakan dan mempertukarkan produk atau jasa bank yang ditujukan untuk memenuhi kebutuhan dan keinginan nasabah dengan cara memberikan kepuasan. Berdasarkan defenisi tersebut beberapa pengertian yang perlu untuk diketahui adalah :

a. Produk bank adalah jasa yang ditawarkan kepada nasabah untuk mendapatkan perhatian, untuk dimiliki, digunakan atau dikonsumsi untuk memenuhi kebutuhan dan keinginan nasabah. Produk bank terdiri dari produk simpanan (giro, tabungan dan deposito), pinjaman (kredit) atau jasa-jasa bank lainnya seperti transfer, kliring, inkaso, safe deposit box, kartu kredit, letter of credit, bank garansi, traveller cheque, bank draft, dan jasajasa bank lainnya.

b. Permintaan suatu keinginan manusia yang mendukung oleh daya belinya.
Artinya, permintaaan akan terjadi apabila konsumen memliki sejujmlah dana atau barang pengganti untuk memperoleh barang yang lain.

c. Pertukaran adalah tindakan untuk memperoleh sesuatu barang yang diinginkan dari seseorang dengan menawarkan sesuatu sebagai penggantinya.

d. Pasar adalah himpunan nasabah (pembeli nyata dan pembeli potensial) atas suatu produk, baik barang maupun jasa. Pasar dapat diartikan pula sebagai tempat penjual dan pembeli melakukan transaski.

e. Kebutuhan nasabah bank adalah suatu keadaan yang dirasakan tidak ada dalam diri seseorang.

f. Keinginan nasabah bank adalah kebutuhan yang dibentuk oleh kultur dan kepribadian individu.

\section{Pengertian Internet banking}

Internet banking merupakan produk perbankan elektronik yang ditawarkan pihak bank untuk memberikan kemudahan kepada nasabah dalam melakukan transaksi perbankan melalui komputer dan jaringan internet (Suryani, 2005:42). Sedangkan menurut Maharsi (2006:22) internet banking adalah salah satu pelayanan jasa bank yang memungkinkan nasabah untuk memperoleh informasi, melakukan komunikasi, dan melakukan transaksi perbankan melalui jaringan internet dan bukan merupakan bank yang hanya menyelenggarakan layanan perbankan melalui internet. Dengan kata lain, suatu bank yang memiliki website tetapi tidak dapat digunakan untuk bertransaksi tidak termasuk dalam internet banking.

Kelebihan Layanan Internet banking Kelebihan layanan internet banking adalah : 
1. Hemat waktu, tidak perlu meninggalkan meja kerja Anda untuk melakukan aktivitas perbankan cukup menggunakan personal komputer atau laptop yang dilengkapi dengan koneksi internet.

2. Kapan saja, tak terbatas waktu untuk bertransaksi atau sekedar melakukan cek saldo dan melihat mutasi rekening.

3. Dimana saja, dapat melakukan transaksi dari belahan dunia manapun selama ada akses ke internet.

4. Mudah, menu transaksi dengan navigasi jelas, walaupun baru pertama kali menggunakannya.

5. Aman, dilengkapi sistem keamanan berlapis dengan menggunakan PIN number.

6. Satu akses untuk semua produk, dengan login hanya menggunakan User ID anda dapat sekaligus mengakses seluruh produk yang Anda miliki dalam satu CIF.

7. Registrasi mudah, melalui ATM kemudian Anda bisa langsung melakukan aktivasi dan mengakses rekening Anda.

8. Tanpa software khusus, Anda tidak memerlukan software khusus, cukup gunakan minimum konfigurasi dengan browser.

9. Hemat. Hampir seluruh fitur yang ada. dapat digunakan secara gratis.

Beberapa keunggulan ekonomis melakukan aktivitas perbankan dengan menggunakan Internet banking, antara lain:

1. Menaikkan Tingkatan Layanan (sevice level)

Dengan ATM, nasabah tidak bergantung lagi pada jam kerja bank dan tidak buang waktu untuk antri. Langkah ini diambil untuk memuaskan nasabah dan mempertahankan kesetiaan mereka.
2. Mempercepat Antara Jasa

Transfer infomasi dan dana nasabah akan sampai hanya dengan hitungan menit atau bahkan detik.

3. Meningkatkan Efisiensi

Satu unit dibank hanya memerlukan sedikit karyawan tetapi tejamin akurasinya.

4. Meningkatkan produktivitas karyawan Komputer akan mendayagunakan karyawan untuk menyelesaikan tugas lebih banyak tetapi dengan kurun waktu minimal.

Faktor-Faktor yang Mempengaruhi Keputusan Nasabah Menggunakan Internet banking

Faktor-faktor yang mempengaruhi nasabah dalam menggunakan layanan internet banking antara lain :

1. Persepsi Kemudahan untuk Menggunakan (Preceived Easy of Use) Menurut Ma'aruf (dalam Febriansyah, 2010:22) persepsi terhadap kemudahan untuk menggunakan internet (perceivedeasy of use) adalah persepsi nasabah bank terhadap kemampuan mereka dalam menggunakan internet. Menurut Pavlou (dalam Febriansyah, 2010:23) persepsi kemudahan didefenisikan sebagai tingkat kepercayaan seseorang bahwa dalam menggunakan suatu sistem akan terbebas dari usaha.

Pengertian perspektif kemudahan di atas memberikan indikasi bahwa suatu sistem dirancang bukan untuk menyulitkan pemakaiannya, akan tetapi penggunaan sistem justru mempermudah seseorang dalam menyelesaikan perkerjaanya. Dengan kata lain, seseorang yang menggunakan sistem akan berkerja lebih mudah dibandingkan dengan seseorang yang tidak menggunakan sistem atau manual. Kemudahan 
penggunaan internet banking berarti bahwa layanan internet banking yang telah disediakan oleh bank mudah di fahami dan mudah untuk digunakan sehingga akan mengurangi usaha nasabah untuk mempelajari bagaimana cara bertransaksi menggunakan internet banking. Menurut Nasution (2006:19), menyatakan bahwa intensitas penggunaan dan iteraksi antara pengguna (user) dengan sistem juga menunjukkan kemudahan penggunaan. Dengan kata lain, suatu sistem yang lebih dikenal, lebih mudah dioperasikan, dan lebih mudah digunakan oleh para nasabahnya.

Berdasarkan uraian diatas, dapat disimpulkan bahwa penerimaan suatu sistem internet banking dipengaruhi oleh kemudahan penggunaan internet banking tersebut. Hal ini disebabkan karena pemakai atau nasabah akan bersikap terbuka sesuatu yang sesuai dengan apa yang dapat di fahami dengan mudah. Selain itu, layanan internet banking tersebut juga dianggap bermanfaat bagi pemakai sehingga akan mendorong pemakai untuk mengadopsi dan menggunakan sistem tersebut.

2. Persepsi pada kemanfaatan (Perceived Usefulness)

Menurut Ma'aruf (dalam Febriansyah, 2010:23) dan, persepsi atas daya guna internet (perceived usefulness) yaitu persepsi pengguna internet terhadap daya guna internet. Menurut Pavlou (dalam Febriansyah, 2010:24) Persepsi atas dasar guna didefenisikan: "The prospective user's subjective probability that using a specific appllication sysytem will Increase his or her job performance within an organizational context". Kemanfaatan (usefullness) merupakan suatu lingkaran dimana seseroang percaya bahwa penggunaan suatu teknologi tertentu akan meningkatkan prestasi kerja orang tersebut. Manfaat sistem bagi pemakainya berkaitan dengan produktivitas, kinerja tugas atau efektivitas dan kegunaan tugas secara menyeluruh.

Menurut Nasution (2006:19), menjelaskan bahwa kemanfaatan dapat dibagi dalam dua katagori yaitu :

1) Kemanfaatan dengan estimasi satu faktor

Kemanfaatan dengan estimasi satu faktor adalah menjadikan pekerjaan lebih mudah (makes job easier), bermanfaat (usefull), menambah produktivitas (increase productivity), mempertinggi efektivitas (enchance effectiveness), dan mengembangkan kinerja perkerjaan (improve job performance).

2) Kemanfaaatan dengan estimasi dua faktor

Kemanfaatan dengan estimasi dua faktor dibagi menjadi dua kategori yaitu kemanfaatan dan efektivitas.

Kemanfaatan dalam internet banking merupakan manfaat yang diperoleh atau diharapkan oleh para nasabah dalam melaksanakan tugas dan perkerjaannya. Seseorang akan mengadopsi internet banking apabila orang tersebut mempercayai bahwa internet banking dapat memberikan manfaat terhadap perkerjaannya dan pencapaian prestasi kerjannya. Oleh karena itu, tingkat kemanfaatan internet banking mempengaruhi sikap para nasabah terhadap sistem tersebut.

3. Resiko (Risk)

Resiko adalah suatu keadaan uncertainty yang dipertimbangkan 
orang untuk memutuskan atau tidak melakukan transaksi secara online. Orang-orang benar-benar mempertimbangkan jarak dan suasana impersonal dalam transaksi online dan infrastruktur global yang banyak mengandung unsur resiko. Resiko didefenisikan sebagai perkiraan subyektif konsumen untuk menderita kerugian dalam menerima hasil diinginkan (Pavlou dalam Febriansyah, 2010:25). Menurut Dowling dan Staelin (dalam Febriansyah, 2010:25) kalau resiko itu meningkat dari sekedar informasi sampai pada keputusan pembelian produk (transaksi), resiko diasosiasikan dengan kepercayaan.

Dalam penelitian ini indikator resiko dilihat dari tindakan yang dilakukan oleh bank untuk memperkecil resiko dari penggunaan internet banking, diharapkan tindakan yang dilakukan oleh bank untuk memperkecil resiko akan berdampak positif pada niat konsumen untuk menggunakan teknologi yang ditawarkan.

4. Kepercayaan (Trust)

Kepercayaan merupakan faktor penting bagi konsumen untuk memutuskan akan mekakukan transaksi secarai online atau tidak. Menurut Pavlou (dalam Febriansyah, 2010:27) faktor kepercayaan dalam $e$ commerce adalah perkiraan subyektif dimana konsumen percaya mereka dapat melakukan transaksi online secara konsisten sesuai dengan yang diharapkan. Konsep kepercayaan disini adalah kepercayaan pada penyelenggara transaksi online (banking atau retailer/produsen) dan Upaya tinggi harus dilakukan oleh penyelenggara transaksi online agar kepercayaan konsumen semakin tinggi, karena trust mempunyai pengaruh besar pada niat konsumen untuk melakukan transaksi secara online atau tidak melakukannya.

\section{Metode Penelitian}

\section{Populasi dan Sampel Penelitian}

Populasi adalah sekelompok elemen yang lengkap, yang biasanya berupa orang, objek atau kejadian dimana kita tertarik untuk mempelajari suatu objek penelitian (Kuncoro, 2009:115). Populasi dalam penelitian ini adalah nasabah Bank Mestika Rantauprapat. Berdasarkan data Bank Mestika Cabang Rantauprapat, jumlah nasabah Bank Mestika berjumlah 4.015 nasabah. Penentuan jumlah sampel penelitian ini menggunakan rumus Slovin dengan jumlah 98 orang.

\section{Metode Analisis Data Metode Analisis Deskriptif}

Analisis deskriptif adalah kegiatan mengelompokkan, memisahkan, mengatur, mengurutkan, menganalisis serta menyimpulkan data sehingga hasilnya dapat ditafsirkan dan memberikan informasi deskriptif untuk menjawab pertanyaan dari defenisi masalah.

\section{Uji Asumsi Klasik}

Sebelum data dianalisis, maka model regresi berganda harus memenuhi syarat uji asumsi klasik yang terdiri atas :

\section{Uji Normalitas}

Uji normalitas dilakukan untuk menguji apakah dalam model regresi, variabel bebas dan variabel terikat atau keduanya telah terdistribusi secara normal atau tidak. Model regresi yang baik adalah model yang memiliki distribusi normal atau mendekati normal. Normalitas dapat dideteksi dengan melihat penyebaran data (titik) dari sumbu diagonal dari grafik atau melihat histogram dari residualnya. Uji 
normalitas juga dapat dilakukan dengan menggunakan pendekatan KolmogrovSmirnov. Dengan menggunakan tingkat signifikansi 5\% maka jika nilai Asymp.sig (2-tailed) diatas nilai signifikansi 5\% artinya variabel residual berdistribusi normal.

\section{Uji Multikoliniearitas}

Uji model asumsi klasik selanjutnya adalah uji multikoliniearitas. Uji ini dilakukan untuk mengetahui apakah ada korelasi antara variabel independennya (Usman dan Sobari, 2013:75). Konsekuensi penting bagi model regresi yang mengandung multikolinieritas adalah kesalahan standar estimasi akan cenderung meningkat dengan bertambahnya variabel independen, tingkat signifikansi untuk menolak hipotesis nol akan semakin besar, dan probabilitas menerima hipotesis yang salah juga akan semakin besar. Pengujian multikolniearitas dalam penelitian ini dilakukan dengan melihat nilai dari Variance Inflation Factor (VIF) dan nilai Tolerance-nya. Jika nilai VIF < 5 dan nilai Tolerance-nya $>0,1$ maka tidak terjadi multikoliniearitas.

\section{Uji Heteroskedastisitas}

Situmorang dkk (2008:122) menyatakan bahwa uji heteroskedastisitas pada prinsipnya juga ingin menguji apakah sebuah grup mempunyai varians yang sama diantara anggota grup tersebut. Jika varians sama, dan ini yang seharusnya terjadi maka dikatakan ada homoskedastisitas. Sedangkan jika varians tidak sama dikatakan terjadi heterokedastisitas.

Model regresi yang baik adalah bila tidak terjadi heteroskedastisitas. Cara yang dapat dilakukan untuk mendeteksi heteroskedastisitas adalah melihat grafik scatterplot antara nilai prediksi (*ZPRED) dengan nilai residualnya
(*ZRESID). *ZPRED dan *ZRESID merupakan nilai prediksi dan residual yang telah distandarisasi. Nilainya memang berubah, tetapi skalanya tidak, sehingga tetap mencerminkan data sesungguhnya (Usman dan Sobari, 2013:78). Indikasi terjadinya heterosdekastisitas dapat dilihat bila terjadi pola sistematik tertentu pada plot seperti titik-titik yang membentuk pola yang teratur, namun bila tidak terdapat pola yang jelas serta titik-titik nya menyebar maka bisa diindikasikan model regresi bebas dari heterosdekastisitas.

Analisis Regresi Linear Berganda

Analisis regresi linear berganda digunakan untuk menganalisis seberapa besar pengaruh dan hubungan antara variabel bebas dengan variabel terikat. Analisis regresi berganda digunakan karena jumlah variabel bebas yang akan diteliti berjumlah lebih dari satu variabel. Dalam penelitian ini peneliti menggunakan aplikasi SPSS 20 for Windows untuk menghitung model regresi berganda ini. Rumus matematisnya adalah :

$$
\begin{array}{cl}
\mathbf{Y}=\mathbf{a}+\mathbf{b}_{\mathbf{1}} \mathbf{X}_{\mathbf{1}}+\mathbf{b}_{\mathbf{2}} \mathbf{X}_{\mathbf{2}}+\mathbf{b}_{\mathbf{3}} \mathbf{X}_{\mathbf{3}}+\mathbf{b}_{\mathbf{4}} \mathbf{X}_{\mathbf{4}}+\boldsymbol{e} \\
\text { Dimana : } & \\
\mathrm{Y} & =\text { Keputusan nasabah } \\
\mathrm{a} & =\text { Konstanta } \\
\mathrm{b}_{1}, \mathrm{~b}_{2}, \mathrm{~b}_{3} & =\text { Koefisien regresi } \\
\mathrm{X}_{1} & =\text { Persepsi kemudahan } \\
\text { penggunaan } & \text { (Perceived easy of use) } \\
\mathrm{X}_{2} & =\text { Persepsi manfaat } \\
\text { (Perceived } & \text { of usefullness) } \\
\mathrm{X}_{3} & =\text { Kepercayaan (Trust) } \\
\mathrm{X}_{4} & =\text { Resiko (Risk) } \\
e & =\text { Standar error }
\end{array}
$$

\section{Uji Hipotesis}

Uji Signifikansi Parsial (Uji t)

Uji $t$ bertujuan untuk melihat secara parsial apakah ada pengaruh yang signifikan dari persepsi kemudahan 
penggunaan (perceived easy of use) $\left(\mathrm{X}_{1}\right)$, persepsi manfaat (perceived usefulness) $\left(\mathrm{X}_{2}\right)$, dan kepercayaan (trust) $\left(\mathrm{X}_{3}\right)$, dan resiko (risk) $\left(\mathrm{X}_{4}\right)$ terhadap keputusan nasabah untuk menggunakan Internet Banking (Y).

Bentuk pengujiannya adalah :

Ho : bi $=0$ (Variabel bebas secara parsial tidak berpengaruh positif dan signifikan terhadap variabel terikat).

Ha : bi $\neq 0$ (Variabel bebas secara parsial berpengaruh positif dan signifikan terhadap variabel terikat).

Nilai thitung akan dibandingkan dengan nilai $t_{\text {tabel }}$. Kriteria pengambilan keputusan yaitu :

$\mathrm{H}_{0}$ diterima bila $\mathrm{t}_{\text {hitung }}<\mathrm{t}_{\text {tabel }}$ pada $\alpha=5 \%$.

$\mathrm{H}_{1}$ diterima bila $\mathrm{t}_{\text {hitung }}>\mathrm{t}_{\text {tabel }}$ pada $\alpha=5 \%$.

\section{Uji Signifikansi Simultan (Uji F)}

Uji F dilakukan untuk mengetahui apakah secara bersama-sama persepsi kemudahan penggunaan (perceived easy of use) ( $\left.\mathrm{X}_{1}\right)$, persepsi manfaat (perceived usefulness) $\left(\mathrm{X}_{2}\right)$, dan kepercayaan (trust) $\left(\mathrm{X}_{3}\right)$, dan resiko (risk) $\left(\mathrm{X}_{4}\right)$ berpengaruh signifikan terhadap keputusan nasabah menggunakan internet banking (Y). Model hipotesis yang digunakan dalam uji $\mathrm{F}$ ini adalah :

Ho : $b_{1}=b_{2}=b_{3}=b_{4}=0$ (Variabel bebas secara bersama-sama tidak berpengaruh positif signifikan terhadap variabel terikat).

Ho : $b_{1} \neq b_{2} \neq b_{3} \neq b_{4} \neq 0$

(Variabel bebas secara bersama-sama berpengaruh positif dan signifikan terhadap variabel terikat).

Nilai $F_{\text {hitung }}$ akan dibandingkan dengan nilai $F_{\text {tabel}}$. Kriteria pengambilan keputusan yaitu:

pada $\alpha=5 \%$

Ho diterima bila $\mathrm{F}_{\text {hitung }}<\mathrm{F}_{\text {tabel }}$$$
\text { (n) }
$$

.
}

$\begin{aligned} \mathrm{H}_{1} & \\ \text { pada } \alpha & =5 \%\end{aligned}$

$\mathrm{H}_{1}$ diterima bila $\mathrm{F}_{\text {hitung }}>\mathrm{F}_{\text {tabel }}$

\section{Koefisien Determinasi $\left(\boldsymbol{R}^{2}\right)$}

Koefisien determinasi $\left(R^{2}\right)$ bertujuan untuk mengetahui signifikansi variabel. Koefisien determinasi melihat seberapa besar pengaruh variabel independent terhadap variabel dependent. Jika $R^{2}$ semakin besar (mendekati 1 ), maka dapat dikatakan bahwa pengaruh variabel bebas $\left(\mathrm{X}_{1}, \mathrm{X}_{2}, \mathrm{X}_{3}\right.$, dan $\left.\mathrm{X}_{4}\right)$ adalah besar terhadap variabel terikat $(\mathrm{Y})$. hal ini berarti model yang digunakan semakin kuat untuk menerangkan pengaruh variabel bebas yang diteliti terhadap variabel terikat. Sebaliknya jika $R^{2}$ semakin mengecil (mendekati nol) maka dapat dikatakan bahwa pengaruh variabel bebas $\left(\mathrm{X}_{1}, \mathrm{X}_{2}, \mathrm{X}_{3}\right.$, dan $\left.\mathrm{X}_{4}\right)$ terhadap variabel terikat (Y) semakin kecil. Hal ini berarti model yang digunakan tidak kuat untuk menerangkan pengaruh variabel bebas yang diteliti terhadap variabel terikat.

\section{Hasil Dan Pembahasan}

\section{Analisis Regresi Linear Berganda}

Analisis regresi linear berganda ditujukan untuk mengetahui pengaruh atau hubungan variabel bebas $\left(\mathrm{X}_{1}, \mathrm{X}_{2}, \mathrm{X}_{3}\right.$, dan $\mathrm{X}_{4}$ ) yaitu variabel kualitas produk, desain produk, dan fitur produk terhadap variabel terikat $(\mathrm{Y})$ berupa keputusan pembelian. Maka untuk memperoleh hasil yang lebih akurat, peneliti menggunakan bantuan program software SPSS (Statistik Product and Service Solution) versi 20.0 dari tabel coefficient maka dihasilkan output sebagai berikut :

\section{Hasil Analisis Regresi Linear Berganda}

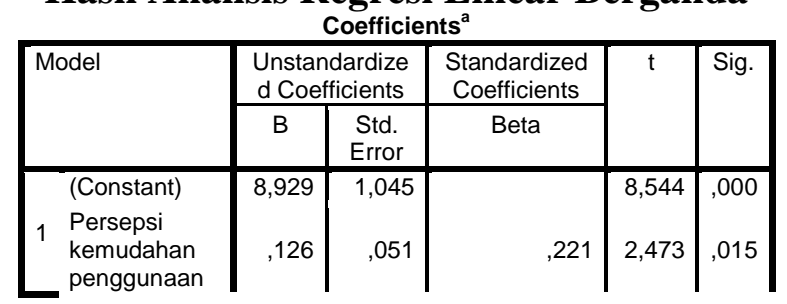


\begin{tabular}{|l|r|r|r|r|r|}
\hline \begin{tabular}{l|r|r|r|} 
Persepsi \\
manfaat
\end{tabular} &, 234 &, 056 &, 378 & 4,180 &, 000 \\
Kepercayaan &, 183 &, 092 &, 221 & 1,996 &, 049 \\
Resiko &, 002 &, 095 &, 002 &, 018 &, 986 \\
\hline
\end{tabular}

Berdasarkan Tabel pada kolom

Unstandardized Coefficients bagian B diperoleh nilai sebagai berikut :

1) Konstanta (a) $=8,929$. Artinya apabila faktor persepsi kemudahan penggunaan $\left(\mathrm{X}_{1}\right)$, persepsi manfaat $\left(\mathrm{X}_{2}\right)$, kepercayaan $\left(\mathrm{X}_{3}\right)$ dan resiko $\left(\mathrm{X}_{4}\right)$ tidak ada atau sama dengan nol, maka keputusan nasabah untuk menggunakan Internet Banking pada PT. Bank Mestika Cabang Rantauprapat adalah sebesar 8,929.

2) Koefisien $X_{1}\left(b_{1}\right)=0,126$. Koefisien regresi variabel persepsi kemudahan penggunaan sebesar 0,126 artinya variabel persepsi kemudahan penggunaan mempunyai pengaruh positif terhadap keputusan nasabah untuk menggunakan Internet Banking pada PT. Bank Mestika Cabang Rantauprapat. Apabila variabel persepsi kemudahan penggunaan naik satu satuan dan variabel lainnya dianggap konstan, maka keputusan nasabah untuk menggunakan Internet Banking sebesar 0,126.

3) Koefisien $X_{2}\left(b_{2}\right)=0,234$. Koefisien regresi variabel persepsi manfaat sebesar 0,234 artinya variabel persepsi manfaat mempunyai pengaruh positif terhadap keputusan keputusan nasabah untuk menggunakan Internet Banking pada PT. Bank Mestika Cabang Rantauprapat. Apabila variabel persepsi manfaat naik satu satuan dan variabel lainnya dianggap konstan, maka keputusan nasabah untuk menggunakan Internet Banking sebesar 0,234.

4) Koefisien $X_{3}\left(b_{3}\right)=0,183$. Koefisien regresi variabel kepercayaan sebesar
0,183 artinya variabel kepercayaan mempunyai pengaruh positif terhadap keputusan nasabah untuk menggunakan Internet Banking pada PT. Bank Mestika Cabang Rantauprapat. Apabila variabel kepercayaan naik satu satuan dan variabel lainnya dianggap konstan, maka keputusan nasabah untuk menggunakan Internet Banking sebesar 0,183.

5) Koefisien $X_{4}\left(b_{4}\right)=0,002$. Koefisien regresi variabel resiko sebesar 0,002 artinya variabel resiko mempunyai pengaruh positif terhadap keputusan nasabah untuk menggunakan Internet Banking pada PT. Bank Mestika Cabang Rantauprapat. Apabila variabel resiko naik satu satuan dan variabel lainnya dianggap konstan, maka keputusan nasabah untuk menggunakan Internet Banking sebesar 0,002 .

Dengan demikian, persamaan regresi yang dihasilkan adalah sebagai berikut :

$$
\begin{gathered}
\mathrm{Y}=8,929+0,126 \mathrm{X}_{1}+0,234 \mathrm{X}_{2}+ \\
0,183 \mathrm{X}_{3}+0,002 \mathrm{X}_{4}+e
\end{gathered}
$$

Pengujian Hipotesis

Hasil Uji Signifikansi Parsial (Uji t) Hasil Uji Parsial (Uji t)

\begin{tabular}{|c|c|c|c|c|c|}
\hline \multirow[t]{2}{*}{ Model } & \multicolumn{2}{|c|}{$\begin{array}{l}\text { Unstandardized } \\
\text { Coefficients }\end{array}$} & \multirow{2}{*}{$\begin{array}{c}\begin{array}{c}\text { Standar } \\
\text { dized } \\
\text { Coeffici } \\
\text { ents }\end{array} \\
\text { Beta }\end{array}$} & \multirow[t]{2}{*}{$t$} & \multirow[t]{2}{*}{ Sig. } \\
\hline & $B$ & $\begin{array}{l}\text { Std. } \\
\text { Error }\end{array}$ & & & \\
\hline (Constant) & 8,929 & 1,045 & & 8,544 &, 000 \\
\hline $\begin{array}{l}\text { Persepsi } \\
\text { kemudahan } \\
\text { penggunaan }\end{array}$ & ,126 & ,051 & ,221 & 2,473 & ,015 \\
\hline $\begin{array}{l}\text { Persepsi } \\
\text { manfaat }\end{array}$ & ,234 & ,056 & ,378 & 4,180 &, 000 \\
\hline Kepercayaan & , 183 & ,092 & ,221 & 1,996 &, 049 \\
\hline Resiko & ,002 & ,095 & ,002 & ,018 & ,986 \\
\hline
\end{tabular}
Coefficients $^{\mathrm{a}}$

Berdasarkan data pada Tabel diatas, maka dapat dijelaskan sebagai berikut : 
a) Untuk variabel persepsi kemudahan penggunaan $\left(\mathrm{X}_{1}\right)$ diperoleh nilai $\mathrm{t}_{\text {hitung }}$ adalah 2,473. Dengan demikian nilai $t_{\text {hitung }}>t_{\text {tabel }}(2,473>1,661)$ dengan taraf signifikansi $(0,015<0,005)$, sehingga dapat dikatakan bahwa persepsi kemudahan penggunaan $\left(\mathrm{X}_{1}\right)$ secara parsial berpengaruh positif dan signifikan terhadap keputusan nasabah menggunakan Internet Banking pada PT. Bank Mestika Cabang Rantauprapat. Dengan demikian hipotesis dapat diterima.

b) Untuk variabel persepsi manfaat $\left(\mathrm{X}_{2}\right)$ diperoleh nilai $t_{\text {hitung adalah }} 4,180$. Dengan demikian nilai $t_{\text {hitung }}>t_{\text {tabel }}$ $(4,180>1,661)$ dengan taraf signifikansi $(0,000<0,005)$, sehingga dapat dikatakan bahwa persepsi manfaat $\left(\mathrm{X}_{2}\right)$ secara parsial berpengaruh positif dan signifikan terhadap keputusan nasabah menggunakan Internet Banking pada PT. Bank Mestika Cabang Rantauprapat. Dengan demikian hipotesis dapat diterima.

c) Untuk variabel kepercayaan $\left(\mathrm{X}_{3}\right)$

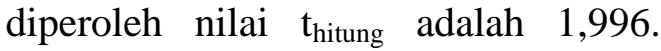
Dengan demikian nilai $t_{\text {hitung }}>t_{\text {tabel }}$ $(1,996>1,661)$ dengan taraf signifikansi $(0,049<0,005)$, sehingga dapat dikatakan bahwa kepercayaan $\left(\mathrm{X}_{3}\right)$ secara parsial berpengaruh positif dan signifikan terhadap keputusan nasabah menggunakan Internet Banking pada PT. Bank Mestika Cabang Rantauprapat. Dengan demikian hipotesis dapat diterima.

d) Untuk variabel resiko $\left(\mathrm{X}_{4}\right)$ diperoleh nilai $t_{\text {hitung }}$ adalah 0,018 . Dengan demikian nilai $t_{\text {hitung }}<t_{\text {tabel }}(0,018<$ $1,661)$ dengan taraf signifikansi $(0,986$ $>$ 0,005), sehingga dapat dikatakan bahwa resiko $\left(\mathrm{X}_{4}\right)$ secara parsial berpengaruh positif dan tidak signifikan terhadap keputusan nasabah menggunakan Internet Banking pada PT. Bank Mestika Cabang Rantauprapat. Dengan demikian hipotesis ditolak.

\section{Hasil Uji Signifikansi Simultan (Uji F)} Hasil Uji Simultan (Uji F)

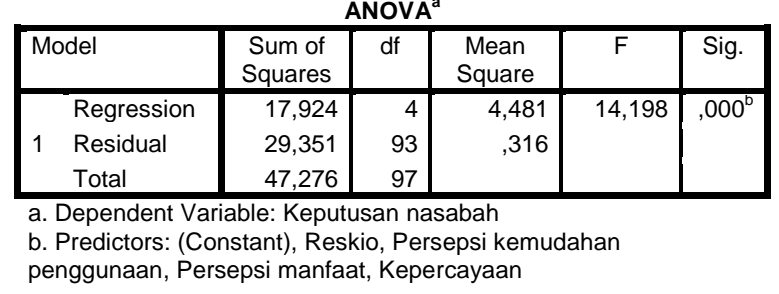

Berdasarkan Tabel di atas, diketahui bahwa nilai $F_{\text {hitung }}$ adalah 14,198 dengan taraf signifikan adalah 0,000. Dengan demikian, nilai $F_{\text {hitung }}$ $(14,198)>F_{\text {tabel }}(2,47)$ dan taraf signifikan $0,000<0,05$. Artinya bahwa variabel persepsi kemudahan penggunaan $\left(\mathrm{X}_{1}\right)$, persepsi manfaat $\left(\mathrm{X}_{2}\right)$, kepercayaan $\left(\mathrm{X}_{3}\right)$, dan resiko $\left(\mathrm{X}_{4}\right)$ secara serempak atau simultan berpengaruh positif dan signifikan terhadap keputusan nasabah menggunakan Internet Banking pada PT. Bank Mestika Cabang Rantauprapat. Dengan demikian hipotesis dapat diterima.

Koefisien Determinasi $\left(\boldsymbol{R}^{2}\right)$

Pengujian koefisien determinasi $\left(R^{2}\right)$ dimaksudkan untuk melihat seberapa besar variabel keputusan nasabah menggunakan Internet Banking pada PT. Bank Mestika Cabang Rantauprapat dapat dijelaskan oleh persepsi kemudahan penggunaan $\left(\mathrm{X}_{1}\right)$, persepsi manfaat $\left(\mathrm{X}_{2}\right)$, kepercayaan $\left(\mathrm{X}_{3}\right)$, dan resiko $\left(\mathrm{X}_{4}\right)$.

Koefisien Determinasi Model Summary

\begin{tabular}{l|r|r|r|c|}
\hline Model & $\mathrm{R}$ & $\begin{array}{c}\mathrm{R} \\
\text { Square }\end{array}$ & $\begin{array}{c}\text { Adjusted R } \\
\text { Square }\end{array}$ & $\begin{array}{c}\text { Std. Error of the } \\
\text { Estimate }\end{array}$ \\
\hline 1 &, $616^{\text {a }}$ &, 379 &, 352 &, 56179 \\
\hline
\end{tabular}
a. Predictors: (Constant), Resiko, Persepsi kemudahan
penggunaan, Persepsi manfaat, Kepercayaan


Pada tabel diatas dapat dilihat nilai Adjusted $R$ Square sebesar 0,352. Hal ini menunjukkan bahwa variabel keputusan nasabah menggunakan Internet Banking pada PT. Bank Mestika Cabang Rantauprapat dapat dijelaskan oleh persepsi kemudahan penggunaan $\left(\mathrm{X}_{1}\right)$, persepsi manfaat $\left(\mathrm{X}_{2}\right)$, kepercayaan $\left(\mathrm{X}_{3}\right)$, dan resiko $\left(\mathrm{X}_{4}\right)$ sebesar $35,2 \%$ dan sisanya sebesar $64,8 \%$ dijelaskan faktor lain yang tidak diibahas dalam penelitian ini.

\section{Pembahasan}

Ada banyak faktor yang dapat mempengaruhi keputusan nasabah untuk menggunakan layanan internet banking, baik itu faktor yang berasal dari dalam diri sesorang itu sendiri maupun faktor ekternal. Teori Technology Acceptance Model (TAM) adalah model yang digunakan untuk menggambarkan perilaku seseorang dalam penggunaan teknologi. Selanjutnya Heilesen dan Jensen (2007:65) menambahkan bahwa TAM juga menjelaskan bahwa individu dapat bebas memilih dalam menggunakan teknologi. Menurut Davis (dalam Wijayanti, 2009) dan Dehgham, Arjomand, Nayyeri, dan Tabatabaey (2012), tujuan utama TAM adalah untuk mendirikan dasar penelusuran pengaruh faktor eksternal terhadap kepercayaan, sikap (personalisasi), dan tujuan pengguna komputer. TAM menganggap bahwa dua keyakinan variabel perilaku utama dalam mengadopsi sistem informasi, yaitu persepsi pengguna terhadap manfaat (perceived usefulness) dan persepsi pengguna terhadap penggunaan (perceived ease of use). Perceived usefulness diartikan sebagai tingkat di mana seseorang percaya bahwa menggunakan sistem tertentu dapat meningkatkan kinerjanya, dan perceived ease of use diartikan sebagai tingkat dimana seseorang percaya bahwa menggunakan sistem tidak diperlukan usaha apapun (free of effort). Perceived ease of use juga berpengaruh pada perceived usefulness yang dapat diartikan bahwa jika seseorang merasa sistem tersebut mudah digunakan maka sistem tersebut berguna bagi pengguna.

Hasil penelitian ini menunjukkan bahwa faktor persepsi kemudahan penggunaan (perceived of easy of use) berpengaruh positif dan signifikan terhadap keputusan nasabah menggunakan layanan internet banking pada PT. Bank Mestika Cabang Rantauprapat. Hal ini dibuktikan berdasarkan hasil uji $t$, dimana nilai $t_{\text {hitung }}$ $(2,473)>t_{\text {tabel }}(1,661)$ dengan taraf signifikansi $0,015<0,005$. Berdasarkan hasil analisis deskriptif diketahui mayoritas responden setuju bahwa bertransaksi dengan internet banking tidak perlu menghabiskan waktu yang lama, internet banking mudah untuk digunakan, dan internet banking sangat fleksibel dalam penggunaannya. Selanjutnya faktor persesi manfaat (perceived of usefullness) juga berpengaruh positif dan signifikan terhadap keputusan nasabah menggunakan layanan internet banking pada PT. Bank Mestika Cabang Rantauprapat. Hal ini dibuktikan berdasarkan hasil uji $t$, dimana nilai $t_{\text {hitung }}$ $(4,180)>t_{\text {tabel }}(1,661)$ dengan taraf signifikansi $0,000<0,005$. Berdasarkan hasil analisis deskriptif diketahui mayoritas responden setuju bahwa produktivitas akan meningkat setelah menggunakan internet banking, transaksi yang dilakukan lebih cepat bila menggunakan internet banking, menggunakan internet banking dapat meningkatkan efektivitas dalam melakukan transaksi perbankan, dan 
fasilitas internet banking sangat berguna. Selain itu, kepercayaan merupakan faktor penting bagi konsumen untuk memutuskan akan mekakukan transaksi secara online atau tidak. Faktor kepercayaan dalah perkiraan subyektif dimana konsumen percaya mereka dapat melakukan transaksi online secara konsisten sesuai dengan yang diharapkan. Konsep kepercayaan disini adalah kepercayaan pada penyelenggara transaksi online banking. Oleh karena itu dan upaya tinggi harus dilakukan oleh penyelenggara transaksi online agar kepercayaan konsumen semakin tinggi, karena kepercayaan mempunyai pengaruh besar pada niat konsumen untuk melakukan transaksi secara online. Dalam hasil penelitian ini menunjukkan bahwa faktor kepercayaan (trust) berpengaruh positif dan signifikan terhadap keputusan nasabah menggunakan layanan internet banking pada PT. Bank Mestika Cabang Rantauprapat. Hal ini dibuktikan berdasarkan hasil uji t, dimana nilai $t_{\text {hitung }}$ $(1,996)>t_{\text {tabel }}(1,661)$ dengan taraf signifikansi $0,045<0,005$. Berdasarkan hasil analisis deskriptif diketahui bahwa mayoritas responden yakin bahwa bank yang menyediakan fasilitas internet banking akan melakukan transaksi seperti yang dijanjikan, transaksi melalui internet banking dapat dipercaya keamanannya, dan layanan internet banking dapat memenuhi segala kebutuhan transaksi perbankan. Faktor lain yang menjadi pertimbangan nasabah dalam melakukan transaksi melalui internet banking adalah resiko (risk). Resiko adalah suatu keadaan uncertainty yang dipertimbangkan orang untuk memutuskan atau tidak melakukan transaksi secara online. Menurut Pavlou (dalam Febriansyah, 2010:25) bahwa resiko didefenisikan sebagai perkiraan subyektif konsumen untuk menderita kerugian dalam menerima hasil diinginkan. Resiko dapat dilihat dari tindakan yang dilakukan oleh bank untuk memperkecil resiko dari penggunaan internet banking, diharapkan tindakan yang dilakukan oleh bank untuk memperkecil resiko akan berdampak positif pada niat konsumen untuk menggunakan teknologi yang ditawarkan. Hasil penelitian ini menunjukkan bahwa faktor resiko (risk) berpengaruh positif dan tidak signifikan terhadap keputusan nasabah menggunakan layanan internet banking pada PT. Bank Mestika Cabang Rantauprapat. Hal ini dibuktikan berdasarkan hasil uji $t$, dimana nilai $t_{\text {hitung }}$ $(0,018)<t_{\text {tabel }}(1,661)$ dengan taraf signifikansi 0,986 >0,005. Berdasarkan hasil analisis deskriptif diketahui mayoritas responden berpendapat bahwa transaksi melalui internet banking memiliki resiko tinggi, akan tetapi aman untuk digunakan dan memiliki potensi yang menguntungkan para penggunanya. Dapat disimpulkan bahwa semakin tinggi resiko menggunakan layanan internet banking, maka akan semakin sedikit nasabah yang menggunakannya.

Secara simultan (serempak) faktor persepsi kemudahan penggunaan (perceived of easy of use), persepsi manfaat (perceived of usefullness), kepercayaan (trust), dan resiko (risk) berpengaruh positif dan signifikan terhadap keputusan nasabah menggunakan layanan internet banking pada PT. Bank Mestika Cabang Rantauprapat. Hal ini dibuktikan berdasarkan hasil uji $\mathrm{F}$, dimana nilai $F_{\text {hitung }}(14,198)>F_{\text {tabel }}(2,47)$ dengan taraf signifikansi $0,000>0,005$. Keputusan nasabah menggunakan Internet Banking pada PT. Bank Mestika Cabang Rantauprapat dapat dijelaskan oleh faktor persepsi kemudahan penggunaan 
(perceived of easy of use), persepsi manfaat (perceived of usefullness), kepercayaan (trust), dan resiko (risk) sebesar 35,2\% sedangkan sisanya sebesar $64,8 \%$ dijelaskan faktor lain yang tidak diteliti.

\section{Kesimpulan Dan Saran}

Berdasarkan hasil penelitian, maka dapat diambil suatu kesimpulan sebagai berikut :

1. Persepsi kemudahan penggunaan (Perceived easy of use) secara parsial berpengaruh positif dan signifikan terhadap keputusan nasabah menggunakan layanan internet banking pada PT. Bank Mestika Cabang Rantauprapat.

2. Persepsi manfaat (Perceived of usefullness) secara parsial berpengaruh positif dan signifikan terhadap keputusan nasabah menggunakan layanan internet banking pada PT. Bank Mestika Cabang Rantauprapat.

3. Kepercayaan (Trust) secara parsial berpengaruh positif dan signifikan terhadap keputusan nasabah menggunakan layanan internet banking pada PT. Bank Mestika Cabang Rantauprapat.

4. Resiko (Risk) secara parsial berpengaruh positif dan tidak signifikan terhadap keputusan nasabah menggunakan layanan internet banking pada PT. Bank Mestika Cabang Rantauprapat.

5. Persepsi kemudahan penggunaan (Perceived easy of use), Persepsi manfaat (Perceived of usefullness), Kepercayaan (Trust), dan Resiko (Risk) secara simultan berpengaruh positif dan signifikan terhadap keputusan nasabah menggunakan layanan internet banking pada PT. Bank Mestika Cabang Rantauprapat.
6. Keputusan nasabah menggunakan layanan internet banking pada PT. Bank Mestika Cabang Rantauprapat mampu dijelaskan oleh faktor Persepsi kemudahan penggunaan (Perceived easy of use), Persepsi manfaat (Perceived of usefullness), Kepercayaan (Trust), dan Resiko (Risk) sebesar 35,2\%, sedangkan sisanya sebesar $64,8 \%$ dijelaskan faktor lain yang tidak dibahas dalam penelitian ini.

Berdasarkan kesimpulan yang telah diuraikan sebelumnya, maka peneliti memberikan saran-saran sebagai berikut :

1. Pihak PT. Bak Mestika Cabang Rantauprapat bank hendaknya dapat menjaga kepercayaan yang telah diberikan oleh para nasabah terhadap bank untuk menjaga keamanan dari simpanan para nasabah dengan cara memberikan pelayanan terbaik bagi nasabah dalam segala aspek transaksi keuangan dan layanan perbankan.

2. Keamanan dalam bertransaksi dengan menggunakan internet banking pada PT. Bank Mestika Cabang Rantauprapat harus terus ditingkatkan dengan melakukan upgrade sistem keamanan transaksi dan penggunaan teknologi terkini. Hal ini perlu dilakukan mengingat maraknya kasus pembobolan yang terjadi pada beberapa perbankan di Indonesia, sehingga menimbulkan rasa cemas dan takut untuk menggunakan fasilitas perbankan internet banking.

3. Pihak manajemen perlu menyarankan kepada para nasabah untuk melakukan pergantian PIN secara berkala dan mengganti kartu ATM dan kartu kredit dengan sistem chip. Ini semua dilakukan untuk menjaga kenyamanan para nasabah dalam melakukan 
transaksi perbankan, baik secara online maupun secara mandiri.

\section{Daftar Pustaka}

Dehghan, Alireza, Parham Arjomand, Amirahmed Nayyeri, dan Masoud Tabatabaey. (2012). Offering a Conceptual Model of Technology Acceptance in e-Banking Based on the Customers" Satisfaction and Trust. Dipublikasikan melalui Park, Jong Hyuk, Han-Chieh Chao, James J. Park, Mohammad Obaidat, dan Jongsung Kim. Computer Science and Convergence: CSA 2011 \& WCC 2011 Proceedings, pp. 415-426. Dordrecht: Springer Science+Business Media.

Febriansyah, Andi Hakim. 2010. Faktor Yang Mempengaruhi Penggunaan Layanan Internet Banking pada PT. Bank BNI (Persero), Tbk Cabang USU Medan. Jurnal Manajemen Bisnis, Vol 3 No. 4. Medan.

Ghozali, Imam. 2007. Aplikasi Analisis Multivariate dengan Program SPSS. Semarang : Badan Penerbit Universitas Diponegoro.

Heilesen, Simon B. dan Sisse Siggaard Jensen. (2007). Designing for Networked Communications: Strategies and Development. Hershey, PA: Idea Group Publishing (an imprint of Idea Group Inc.).

Kasmir. 2008. Pemasaran Bank. Prenada. Jakarta : Media.

Kuncoro, Mudrajad. 2009. Metode Riset untuk Bisnis \& Ekonomi (Edisi 3). Jakarta : Erlangga.
Kurniawan, David. Samuel, Natahe. Japarianto, Edwin. 2013. Jurnal Manajemen Pemasaran. Vol. 1, No. 1, (2013) 1-13. Universitas Kristen Petra.

Maharsi, Sri dan Fenny. 2006. Analisa Faktor-faktor yang Mempengaruhi Kepercayaan dan Pengaruh Kepercayaan Terhadap Loyalitas Internet Banking di Surabaya. Jurnal Akuntansi dan Keuangan, Vol. 8 No.1.

McLeod, Raymond Jr. 2008. Sistem Informasi Manajemen. Edisi Ketujuh, Jilid Satu. Penerbit PT. Prenhallindo: Jakarta.

Nasution, Fahmi Natigor. 2006. Penggunaan Teknologi Informasi Berdasarkan Aspek Perilaku (Behavior Aspect). USU Digital Library.

Presetijo, R dan Ihalauw, J. 2006. Perilaku Konsumen. Yogyakarta : Andi Offset.

Rahardjo, B. 2006. Aspek teknologi dan Keamanan Dalam Internet Banking. Penerbit: PT. Indocisc: Jakarta.

Situmorang, Syafrizal Helmi, dkk. 2008. Analisis Data Penelitian (Menggunakan Program SPSS). Medan : USU Press.

Sugiyono. 2006. Metode Penelitian Kuantitatif, Kualitatif dan $R \& D$. Bandung : Alfabeta.

Suryani, Tatik, Iifitriah, Anik Mashcudah, dan Santoso. 2005. Sikap dan Penerima Nasabah Terhadap Layanan Internet Banking. Ventura, Vol. 8 No. 2. Jakarta.

Susilowati, D. 2007. Studi Empiris Tentang Faktor-faktor Penerimaan Nasabah Terhadap Layanan Internet Banking (Penelitian pada Perbankan di 
daerah Istimewa Yogyakarta). Skripsi Sarjana, Fakultas Ekonomi Universitas Islam Indonesia. Yogyakarta.

Usman, Hardius dan Nurdin Sobari. 2013. Aplikasi Teknik Multivariate untuk Riset Pemasaran. Jakarta : PT. Raja Grafindo Persada.

Wijayanti, Ratih. 2009. Analisis Technology Acceptance Model (TAM) Terhadap Faktor-faktor yang Mempengaruhi Penerimaan nasabah Terhadap Layanan Internet Banking (Studi Empiris Terhadap Nasabah Bank di Depok). Depok : Univ 